\title{
BLURRING THE BOUNDARIES BETEEEN ORALITY AND LITERACY
} $\mathrm{J} T$ von Gruenewaldt
Department of English: Further Training Campus Vista University

1 Introduction

The aim in this paper is to explore the appropriateness of the categories of orality and literacy for understanding the nature of the relationship that holds between spoken and written modes' of language behaviour. ${ }^{2}$ The problematic nature of the relationship between orality and literacy is one that has long been a topic of interest to linguists. Early research in the 1960 s and 1970 s on the nature of this relationship was based on the assumption that orality and literacy represent two distinct modes of language behaviour, that the relationship between them is that of a dichotomy. Current research findings, however, have caused certain linguists ${ }^{3}$ to question whether the assumed oralliterate dichotomy is consistent with the properties of spoken and written discourse.

Can orality and literacy be characterized according to distinctive linguistic features? Are the differences between them absolute or blurred? Does the oral-literate dichotomy account for the way in which features associated exclusively with each mode are seen to interact in both spoken and written discourse?

The assumption of an oral-literate dichotomy

The tendency to regard orality and literacy in terms of categories has its origins in the work of certain cultural anthropologists ${ }^{4}$ in the 19605 who assume that there is a 'great divide' or 'sharp dichotomy' (Goody 1986:182-183) between oral and literate societies. The claims that these anthropologists assert about the cognitive and cultural consequences of literacy for oral societies constitute what is termed the 'literacy hypothesis'.5 
The central claims of the literacy hypothesis can be expressed as follows:

- Writing causes the relationship between a word and its referent to be more abstract: written discourse car therefore achieve autonomy", whereas spoken discourse is dependent on a context.

The development of literacy as a mode of language behaviour has consequences for human cognition: the cognitive processes of literate individuals are more logical, more complex and more abstract than those of individuals who are not literate.

In terms of this hypothesis, 11teracy is assumed to bring about a restructuring of human consciousness: once the individuals in an oral society have acquired literacy, they will be able to advance in various ways, e.g. socially, culturally, politically, economically, scientifically. However, the claims of the Iiteracy hypothesis are now no longer regarded as true. ${ }^{7}$ There is much anthropological evidence of analytical, abstract, logical thinking by individuals in societies that do not have Iiteracy.

It was not only the Ifteracy hypothesis that influenced certain linguists and classical scholars ${ }^{8}$ to regard orality and literacy as representing two separate modes of language behaviour. Another factor that led to the assumption of two distinct categories is that oral discourse and literate discourse usually differ in purpose and function and are generally produced in differing spatio-temporal circumstances. The differences in the modes of production have given rise to the generalization that there is a difference in the two end-products, namely spoken and written discourse (Chafe 1979 [1984:1095]). Early Iinguistic research in this field, therefore, tended to be contrastive, focusing on opposing lexical and syntactic features associated with each mode. The nature of the relationship between these modes of discourse was thus assumed to be that of a dichotomy. 
Tannen (1982b:39-48; 1985:127-143) identifies, on the basis of the claims they express, two main hypotheses that were advanced in support of the assumed oral-literate dichotomy. These are the contextualization hypothesis and the cohesion' hypothesis.

\subsubsection{The contextualization hypothesis}

The central claims expressed by the contextualization hypothesis can be formulated as follows:

- Typical oral or spoken discourse is contextualized.

- Typical literate or written discourse is decontextualized or autonomous.

In terms of the contextualization hypothesis, typical oral or spoken discourse is assumed to be dependent on a context for interpretation as it generally occurs between a speaker and a hearer who are co-present in time and place, and who share certain knowledge and experience of the world. Typical literate or written discourse, however, is assumed to be independent of a context as it takes place between a writer and a reader who are generally separated in time and place and who do not necessarily share knowledge or experience of the world. Written discourse is thus assumed to be autonomous, i.e. to be comprehensible on its own, without reference to its context: whatever is needed for comprehension is included in the words of the text.

\subsubsection{The cohesion hypothesis}

The central claims expressed by the cohesion hypothesis can be formulated as follows:

- Typical oral or spoken discourse relies on prosodic or paralinguistic cues to establish cohesion.

- Typical literate or written discourse relies on lexicalization and syntactic devices to establish cohesion.

A derivative claim expressed by this hypothesis is that literate 
or written discourse is characterized by a higher lexical density ${ }^{10}$ and greater syntactic complexity than oral or spoken discourse.

2.2

Foaturos essociated uith orality and literacy in terma of the oral-1iterate alchotomy

Among those linguists who have advanced arguments in support of the assumed oral-literate dichotomy, Ochs (1979) and chafe (1979 [1984]," 1982) are the most prominent. Based on their work, an inventory of assumed differences between informal oral discourse and formal expository literate discourse can be schematically represented as in the table below.

The influence of the oral-literate dichotomy and its supporting hypotheses is evident in the features ochs (1979) and chafe (1979 [1984], 1982) posit as characterizing spoken and written discourse respectively.

Spoken discourse is regarded as being contextualized, as being characterized by involvement and syntactic fragmentation, and as establishing cohesion through paralinguistic cues. Written discourse is regarded as being autonomous, as being characterized by detachment and as establishing cohesion by means of lexicalization and syntactic devices.

The influence of the oral-literate dichotomy is also evident in many conventional perceptions about literate discourse. In a literate society, there is a tendency to accord a higher status to the written mode. Writing is regarded as being more permanent, more binding and more authoritative than speech. It is assumed that the production of written discourse requires higher order cognitive skills and a greater mastery of lexical and syntactic devices than the production of spoken discourse. 
FEATURES ASSOCIATED WITH ORAL AND IITERATE DISCOURSE IA TERHS OF THE ORAL-LITERATE DICHOTOMY

(Based on ochs (1979) and chafe (1979 [1984], 1982)

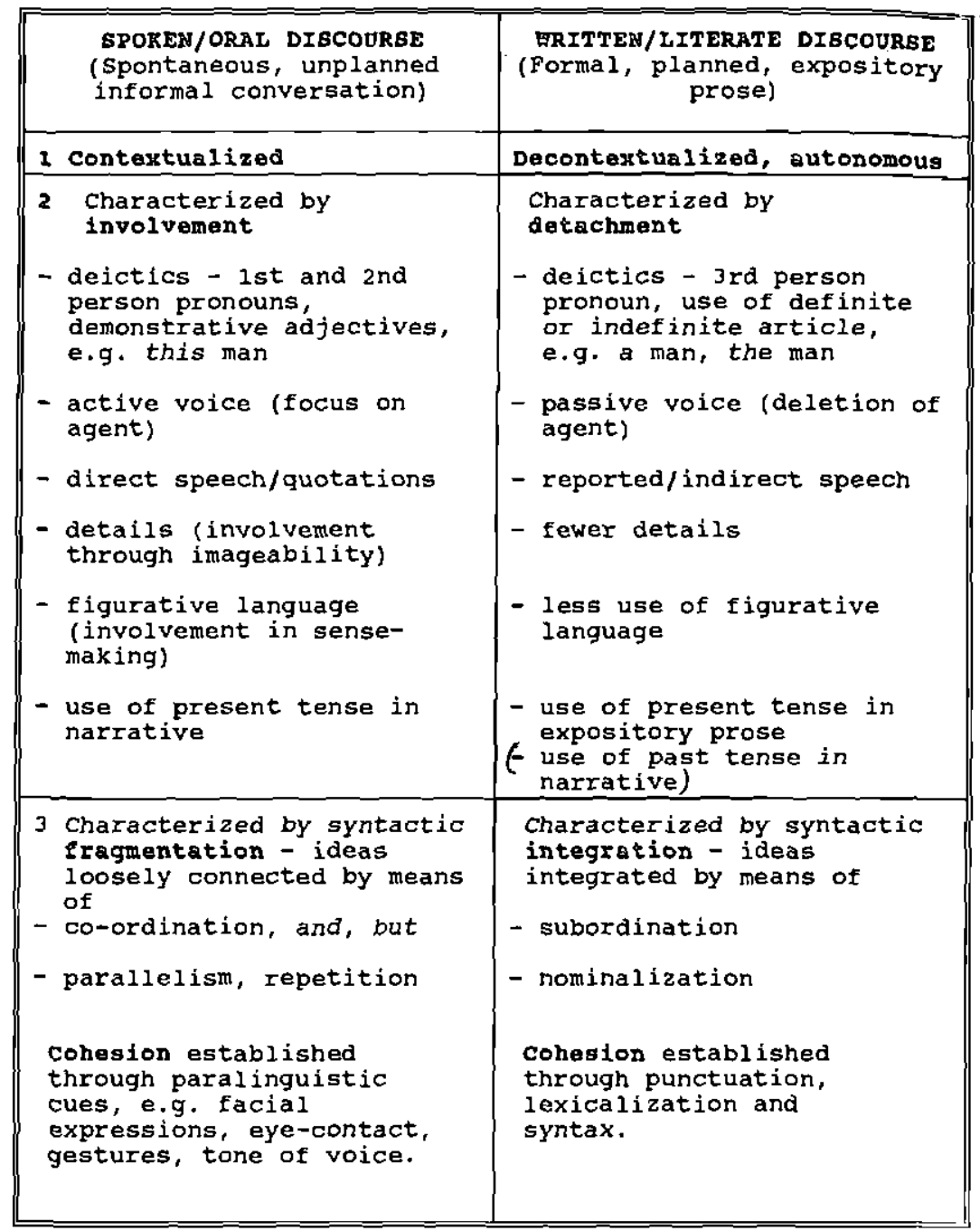


A strong challenge to the assumed oral-literate dichotomy comes from Tannen (1982a, 1982b, 1982c, 1985). Firstly, Tanneh (19820:5) criticizes the findings of most previous research on the relationship between orality and literacy, in particular, the findings of Ochs (1979) and chafe (1979 [1984], 1982), as the discourse types on which they base their analyses are not representative of the same genre. Secondly, Tannen (1982c:3) criticizes the supporting hypotheses of the oral-literate dichotomy. She claims that they do not account for the interaction she observes between features associated with orality and literacy in discourse of either mode.

\subsection{The role of genre}

Tannen (1985:129) characterizes genre ${ }^{12}$ as being a specific mode of discourse, either spoken or written, the communicative purpose of which influences and constrains linguistic choice and style. She (1982c:5) maintains that the samples from which ochs (1979) and chafe (1979 [1984], 1982) draw their data are so different that a comparison between them in terms of mode differences will yield meaningless results. Ochs (1979:55) bases her claims about the differences between oral and literate discourse on comparative analyses of unplanned spoken discourse (casual conversation and narratives) and planned written discourse (personal narratives). Chafe (1979 [1984:1098-1101]) bases his claims about the dichotomous relationship between orality and literacy on comparative analyses of informal spoken discourse and formal expository prose. According to Tannen (1985:124) spontaneous conversation and expository prose can merely be said to 'typify' but not 'exhaustively characterize' spoken and written discourse respectively. A comparison between such disparate genres will not shed light on the relationship between orality and literacy.

Tannen (1982c:6) therefore maintains that the features that ochs (1979) and Chafe (1979 [1984]) claim to be characteristic of oral and literate discourse respectively, could grow out of the respective genres and contexts rather than out of the spoken. and 
written modes.

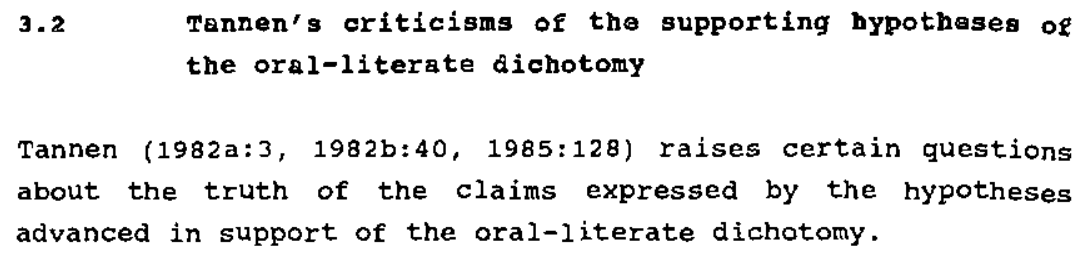

Tannen (1982c) carries out comparative analyses of spoken and written discourse of the same genre, namely narrative. Her aims in doing so are:

- to test the appropriateness of the categories of orality 
437

and literacy for promoting insight into the nature of the relationship that holds between these modes, and to verify her contention that the differences purported to exist between oral and literate discourse are to be ascribed to differences in genre rather than mode.

Tannen (1982c:8) analyses 36 pairs of narratives, each pair produced by the same person, and each pair representing a spoken and a written version of the same narrative. She finds that, in general, the spoken and written versions of each narrative do conform to the expectations of Ochs (1979) and chafe (1979 [1984]) for oral and literate discourse. However, one narrative, namely the written version of what she terms the 'Fernandez' narrative, deviates from these expectations in that it exhibits an interaction of certain features previously associated exclusively with oral or written discourse.

The following comparative analyses of fragments of the 'Fernandez' narratives illustrate the ways in which the written version is problematic in terms of the oral-literate dichotomy:

(1) (a) oh, I have to tell you about this guy at work, Fernandez. He is so funny. He is from south America, from Chile .... (Spoken)

(b) At my agency, there's a man who is Mr Politeness. He doesn't say 'Hi,' he says 'Good morning' and 'Good afternoon.' Instead of calling me 'Della' he calls me 'Mrs Whittaker.' And he dresses as if he worked in a business corporation downtown instead of for the Government at a field office. He is from chile, south America .... (Written)

Examples (1)(a) and (1) (b), representing spoken and written fragments of the same narrative respectively, do conform in certain ways to the expectations established by ochs (1979) and chafe (1979 [1984]) for the categories of oral and literate discourse. These are as follows:

- The spoken and written fragments reflect an opposition of fragmentation and integration respectively. The spoken version (1) (a) exhibits fragmentation in the way in which the ideas are loosely connected, e.g. He is so funny. He is 
from South America. The written version (1) (b) exhibits integration in the syntactically more complex ways in which propositions are combined through devices involving subordination, e.g. ... there's a man who is Mr politeness.... And he dresses as if he worked in a business corporation downtown instead of for the Government at a field office....

There is also a difference in the use of deictic modifiers. In the spoken version (1) (a), a demonstrative modifier is used, e.g. this quy, which implies that the speaker is including or involving the listener in the situation. The use of this demonstrative is a strategy whereby speakerlistener involvement is achieved. In the written version (1) (b), an indefinite modifier is used, e.g. a man, which does not involve the reader in the situation. The use of the indefinite modifier is a strategy whereby detachment is achieved.

However, the written version (1)(b) deviates from ochs' (1979) and Chafe's (1979 (1984)) descriptions of spoken and written discourse in that it exhibits features previously regarded as exclusive to oral discourse. The written version contains instances of direct speech, is characterized by greater imageability than the spoken version as it is richer in detail, is expressed in the present tense and is longer and more elaborate than the spoken version. Tannen (1982c:13) maintains that the written version (1) (b) displays more rather than fewer features associated with spoken discourse than does the spoken version (1) (a).

Examples (2)(a) and (2)(b) exhibit certain features that are counter to the expectations established by Ochs (1979) and chafe (1979 [1984]) for oral and literate discourse respectively:

(2) (a) so then, ... I see: ... that he has on such a nice suit one day. (Spoken)

(b) One day I was praising him for his spiffy attire, a really neat pin-striped suit with a white long-sleeved shirt and a dark tie. (Written) 
Ways in which these fragments do not conform to the description by ochs (1979) and chafe (1979 [1984]) are as follows:

The written version (2) (b), although more elaborate in detail, does not display greater syntactic complexity than the spoken version (2)(a). The spoken fragment exhibits subordination, e.g. I see:... that he has on such a nice suit one day. This is a feature associated with written discourse. The written version does not integrate propositions by means of subordination, but through phrases joined in series.

The written version includes more details than the spoken version, e.g. spiffy attire, a really neat pin-striped suit with a white long-sleeved shirt and a dark tie. The effect of these details is to achieve imageability which, according to Tannen (1982c:14) involves the imagination of the reader in the making of meaning.

The written version is expressed in the present tense. This is a deictic strategy whereby the involvement of the reader is achieved. The reader is addressed as though he or she were a participant in the spatio-temporal circumstances of the discourse.

According to Tannen (1982c:13), the written version (2) (b) also exhibits more features associated with spoken discourse than does the spoken version (2)(a). She claims that the writer deliberately elaborates strategies associated with spoken discourse to involve the reader in the discourse.

Examples (3)(a) and (3)(b), representing spoken and written fragments respectively, display differences in levels of syntactic complexity that are in keeping with the expectations set up by ochs (1979) and Chafe (1979 [1984]) for the categories of orality and literacy:

(3) (a) ... And he knows Spanish, and he knows French, and he knows English, and he knows German, ... and he is a gentleman, ... (Spoken)

(b) He knows at least four languages fluently - Spanish, French, English, and something else... (written) 
The spoken version (3) (a) displays syntactic fragmentation in that the parallel clauses are loosely connected by the conrective and, e.g. And he knows Spanish, and he knows French, and he knows German,... The written version displays syntactic integration in that the ideas are integrated into the sentence by means of lexicalization, e.g. four languages fluently...

However, the written fragment (3) (b) deviates from Ochs' (1979) and Chafe's (1979 (1984)) description of spoken and written language. The written fragment exhibits a feature associated with spoken discourse, namely parallelism. The parallel clauses of the spoken version are here conflated to a series of nouns, e.g. Spanish, French, Enqlish.... This is a feature basic to face-to-face spoken discourse. Tannen (1982c:14) maintains that this interaction she observes between features associated with orality and literacy in the written version (3) (b) is a strategy whereby interpersonal involvement is achieved. The 'rhythmic force' of these parallel constructions appeals to the senses of the reader, involving hitn or her in an awareness of Fernandez' fluency in various languages.

Examples (4) (a) and (4) (b) do not conform to the characteristics that ochs (1979) and chafe (1979 [1984]) posit for oral and literate modes of discourse:

(4) (a) I say, Aaaaahhh, Monsieur, ... comment ca va:, because I can't think of how to say it in Spanish. or he walks in, and I say, Gracias ... Senor Fernandez, $\ldots$ and he says, Buenas dias, ... Senora whittaker. (spoken)

(b) Whatever language I speak to him in, he answers in that language. I'll say, 'Bonjour, Monsieur Fernandez, comment ca va?' And he'll answer 'Il va bon,' or whatever the French say. He always says the right thing in the right language. But me, I forget what language $I$ 'm supposed to answer in, and $I$ usually answer in some other language. Like if he asks, 'Comment ca va?' I answer, 'Va est gut, gracias.' (Written)

- In the spoken version (4) (a), the speaker would probably convey the humour of the situation by means of paralinguistic features such as gestures, facial expressions and intonation. However, the written version, (4) (b) exploits direct speech to convey the humorous 
contrast in the foreign language abilities of the speakers.

- There is no significant difference in the levels of syntactic complexity between the spoken and the written versions. Both exhibit instances of integration by means of syntactic devices involving subordination, e.g. in (4) (a) because I can't think of how to say it in spanish... and in (4) (b) ... if he asks. 'Comment ca va?' I answer, 'Va es gut aracias,' Both exhibit instances of fragmentation in the use of the connective and.

- The written version is more elaborate and detailed than the spoken version, resulting in higher imageability.

- The written version contains two informal colloguial expressions typical of spoken discourse, But_me... and Like....

- The written version is expressed in the present tense. This is a deictic strategy through which the involvement of the reader in the temporal circumstances of the events is achieved.

Tannen (1982c:17) concludes that the written version of the 'Fernandez' narrative is more 'spoken-like' than the spoken version. She ascribes this 'aberration', in terms of the expectations set up for oral and literate discourse, to the nature of the genre. The written version of the 'Fernandez' narrative is a short story, 16 a genre that 'makes use of features associated with oral language because it depends for its effect on interpersonal involvement or the sense of identification between the writer or the characters and the reader' (Tannen 1982a:14). The written version of the 'Fernandez' narrative engages the emotions of the reader in the following ways:

- The use of details resulting in high imageability evokes the reader's imaginative participation in the narrative.

- Patterns of sound, such as parallel structures, appeal to the reader's sense of rhythm.

- Deictics, such as demonstrative modifiers and the present tense, involve the reader as a participant in the circumstances of the narrative.

- Direct speech and colloquialisms convey the impact of the narrative. 
442

The oral-iiterate dichotomy does not account for this interaction between features associated with orality and literacy. Tannen (1982c:1) therefore concludes that the relationship between orality and literacy is more complex than that of a mere dichotomy; it is one that is dynamic and intertwined.

5 Relative focus on interpersonal involvement or content as the key dimension distinguishing discourse

On the basis of her findings on this 'aberrant' pair of narratives, Tannen (1982c:18) asserts a new theory about the relationship between orality and literacy. The central claims of her theory are as follows:

- The key dimension distinguishing discourse is not the oral or the literate mode in which the discourse is physically realized, but the relative focus on interpersonal involvement or on content.

- The nature of the genre of the discourse, whether oral or written, influences the extent to which the discourse focuses on interpersonal involvement or on content.

Tannen's (1984:124) theory about relative focus on interpersonal involvement or on content as the key dimension distinguishing discourse, has greater appeal as an 'explanatory hypothesis' than the oral-literate dichotomy. It is not restricted to issues of orality and literacy, but can account for the way in which various uses of contextualization and cohesion can be manipulated in both speech and writing to produce discourse that is maximally or minimally involving of the audience or reader. Relative focus on involvement or on content is 'the dynamic motivating linguistic choice in discourse' (Tannen 1984:2).

5.1 Implications of relative focus on interpersonal involvement or content for academic literacy

What are the implications of Tannen's theory of relative focus on interpersonal involvement or on content for understanding academic literacy? Tannen's theory of involvement- and information-focused strategies provides insight into the way in 
which the expository genres used in the academic environment depend, for comprehension, on an interaction of features associated with orality and literacy.

Academic discourse, whether spoken or written, comprises a set of genres developed within the setting of the school or university where the focus is on learning. The language of academic discourse is formalized to express the type of abstract, logical, analytical thought processes fostered in the university enviromment. The genres most frequently employed in the academic environment, such as expository essays or formal academic lectures, conventionally focus on content or topic and de-emphasize interpersonal involvement, in contrast to the narrative genre which is maximally involving of the audience (Tannen 1985:137).

Tannen (1985:140) maintains that features associated with orality, such as contextualization and interpersonal involvement, are the basis of all successful discourse, whether spoken or written. According to her (1988:40), the genre of the academic paper presented at a scholarly conference exemplifies this interaction between features associated with orality and literacy. The academic paper represents a planned, expository genre realized in the spoken mode. Although it is essentially literate in that it is written for eventual publication in an academic journal, it is simultaneously oral as it is intended for presentation before a scholarly audience. The paper is structured according to the pattern of the expository essay, expressing a thesis and incorporating supporting arguments. The writer of the paper strives for maximal explicitness in order to rule out any possibility of ambiguity, vagueness or imprecision. To achieve this, the writer makes as few demands upon the audience as possible by filling in referents, supplying background information in the form of notes or footnotes, and clearly stating crucial premisses and their supporting arguments.

However, maximal explicitness should not be equated with autonomy. Although an academic paper may achieve maximal explicitness, it cannot be interpreted on its own. The academic 
paper is contextualized in that it is written for a 'context of eventual use' (Nystrand 1987:205), namely for an audience at a scholarly conference or for readers of a scholarly journal. In order to be interpreted, the paper is dependent on the involvement of the audience or the readers. To construct an interpretation for the paper, the audience or the readers need to follow the reasoning of the discourse by matching the propositions, the claims and the conclusions with expectations based on their knowledge of the discipline. Tannen (1988:40) therefore states that the academic paper exhibits a 'rich texture' or mix of features of orality and literacy. A dichotomous view of orality and literacy does not explain this mix of features associated with each mode. Tannen (1982a:3) therefore claims that when literacy is introduced, it does not replace orality; it is superimposed upon and intertwined with orality. Features that have previously been categorized as distinguishing oral and literate discourse are, in reality, features that reflect relative focus on interpersonal involvement or on content.

\section{Conclusion}

Tannen (1985:127) believes that the categories of orality and literacy have been useful only in a heuristic sense; it is their inadequacy to explain the interaction she observes between features associated with orality and literacy that has made her aware of the need to posit a more satisfactory hypothesis. She (1989:40) therefore eschews a dichotomous view of orality and literacy. Even the notion of an oral-literate continuum does not have the potential to clarify the complex relationship that holds between these modes.

A more adequate explanation for the interactive relationship between orality and literacy, according to Tannen (1988:40), is that they represent integrally related aspects of a single entity, namely a set of involvement strategies whereby relative focus on interpersonal involvement or on content can be achieved in discourse of either mode. 
This article is a revised version of part of a thesis to be submitted to the Department of General Linguistics at the University of stellenbosch in fulfilment of the requirements for the Ph.D. in General Linguistics.

FOOTMOTES

The term 'mode' is used in this paper to refer to a way of behaving linguisticaliy in either the written or the spoken medium. Botha (1994:49) claims that language behaviour can occur in a multitude of different ways or modes. A mode of speaking, listening, writing or reading is in essence, 'a distinct way of using the means in question'. Modes of speaking could range from spontaneous conversation, giving prepared speeches or lectures, to a radio commentary. Modes of writing could range from expository academic writing, informal personal letters, to the compiling of 1 ists.

2 Language behaviour (Botha 1994b:1) consists in 'what people do so as to produce utterances, to assign meaning to utterances - henceforth "comprehend" them - or to judge utterances intuitively'.

3 Beaman (1984:46), Halliday (1987:67), Michaels and collins (1984:220), Nystrand (1987:197), Rader (1982:185) and Tannen (1982a, 1982b, 1982 C, 1985, 1988) are among those linguists who question the appropriateness of the assumed categories of orality and literacy.

4 Anthropologists such as Goody (1986) and Watt (Goody and Watt 1963) assert claims about the consequences of literacy for oral societies.

5 Linguists such as Feldman (1991:47), Narasimhan (1991:177) and Olson (1991:5) classify the general claims about the consequences of literacy as the 'literacy hypothesis'.

6 Textual autonomy is the assumption that a written text is able to be interpreted as it stands on its own, without reference to its context. 'Whatever is needed for comprehension is included in the words of the text' Tannen (1982a:9).

7 The claims of the literacy hypothesis have been criticized by anthropologists such as street (1984), and by linguists such as Heath (1982) and Lakoff (1982). The assumption of a causal relationship between the development of literacy and progress in the social and economic circumstances of a society has also been challenged by cole and scribner (1974) and Graff (1987).

ong (1982:79) makes strong claims for the cognitive and social consequences of literacy.

9 Cohesion consists in the way in which the lexical and syntactic arrangement of a discourse can 'show relationships among ideas, highlight relative importance' or 'foreground or background certain information' (Tannen 1985:130).

10 Lexical density is characterized as the proportion of lexical items to the total discourse. According to Halliday (1987:59), lexical density can be measured in two ways: the ratio of lexical items to total running words, or the ratio of lexical items to the clause. 
11 Chafe's 1979 paper is published in Borbe 1984. References to this 1979 paper are given as 1979 [1984].

12 Various linguists operate with different notions of genre, therefore Swales (1990:33) describes genre as a 'fuzzy concept'. Genre can, however, be characterized as 'a type of discourse, a class of communicative events, spoken or written, the members of which share some set of communicative purposes' (Swales 1990:58).

13 Rader (1982) and Nystrand (1987) reject the claims of the contextualization hypothesis. Rader (1982:127) claims that it is simplistic to assume that the distinction between discourse that is maximally contextualized and discourse that is minimally contextualized corresponds to the distinction between spoken and written language. Nystrand (1987:205) claims that a written discourse is produced for a 'context of eventual use'.

14 Rader (1982:186) cautions against confusing the 'tendency' toward autonomy with the property of autonomy.

15 Beaman (1984:78), Halliday (1987:67) and Nystrand (1987:211) refute the derivative claim of the cohesion hypothesis. They maintain that spoken discourse can be syntactically just as complex, if not more so, than written discourse.

16 Tannen $(1984: 24)$ believes that the narrative genre is primarily a spoken one, and that written narrative borrows many conventions from the spoken storytelling model.

\section{REFERENCES}

Beaman, K. 1984. 'Co-ordination and subordination revisited: Syntactic complexity in spoken and written narrative discourse.' In Tannen, D. (ed.) 1984:45-80.

Botha, R. P. 1994. 'The world of language. 2 Its behavioural belt.' Spil Plus No 25.

Borbe, T. (ed.) 1984. Semiotics unfolding. Berlin: Mouton.

Chafe, w. L. 1979. 'Integration and involvement in spoken and written language.' Paper presented at 2 nd congress of the International Association for semiotic studies, vienna. (Published in Borbe, T. (ed.) 1984: 1095-1102.]

Chafe, $W$. L. 1982. 'Integration and involvement in speaking, writing, and oral literature.' In Tannen, D. (ed.) 1982: $35-54$.

Cole, M. and scribner, s. 1974. Culture and thought: $A$ psychological introduction. New York: John wiley sons.

Feldman, C. F. 1991. 'Oral metalanguage.' In olson, D. R. and Torrance, N. (eds.) 1991:47-65.

Frawley, w. (ed.) 1982. Linguistics and literacy. New York: plenum press.

Goody, Jack, 1986. The logic of writing and the organization of society. Cambridge: Cambridge University Press. 
Goody, J. and Watt, I. P. 1963. 'The consequences of iiteracy.' Comparative studies in society and history 5 . $1968: 304-345$.

Graff, H. J. 1987. The legacies of literacy: Continuities and contradictions in western culture and society. Bloomington: Indiana University press.

Halliday, M. A. K. 1987. 'spoken and written modes of meaning.' In Horowitz, R. and Samuels, S. J. (eds.) 1987:55-82.

Heath, S. B. 1982. 'Protean shapes in literacy events: Evershifting oral and literate traditions.' In Tannen, D. (ed.) $1982: 91-117$.

Horowitz, R. and samuels, S. J. (eds.) 1987. Comprehending oral and written language. San Diego: Academic Press.

Lakoff, R. T. 1982. 'Some of my favourite writers are literate: The mingling of oral and literate strategies in written communication.' In Tannen, D. (ed.) 1982:239 260.

Michaels, S. and collins, J. 1984. 'Oral discourse styles: Classroom interaction and the acquisition of literacy.' In Tannen, D. (ed.) 1984:219-244.

Narasimhan, R. 1991. 'Literacy: Its characterization and implications.' In Olson, D. R. and Torrance, N. (eds.) 1991:177-197.

Nystrand, M. 1987. The role of context in written communication.' In Horowitz, R. and Samuels, S. J. (eds.) $1987: 197-214$.

Ochs, Elinor. 1979. 'Planned and unplanned discourse.' In Givon, T. (ed.) Syntax and semantics Vol 12. 1979:51-80.

olson, D. R., Torrance, N. and Hildyard, A. (eds.) 1985. Literacy, language, and learning: The consequences of reading and writing. Cambridge: Cambridge University Press.

olson, D. R. and Torrance, N. (eds.) 1991. Litexacy and orality. Cambridge: Cambridge University Press.

ong, walter J. 1982. Orality and literacy: The technologizing of the word. London: Methuen.

Rader, M. 1982. 'Context in written lanquage: The case of imaginative fiction.' In Tannen, D. (ed.) 1982:185-198.

street, Brian V. 1984. Literacy in theory and practice. Cambridge: Cambridge University Press.

Swales, J. M. 1990. Genre analysis: English in academic and research settings. Cambridge: Cambridge University Press.

Tannen, D. 1982a. 'The oral/literate continuum in discourse.' In Tannen, D. (ed.) 1982:1-16. 
SPIL PLUS 8 (1983)

TAALWETENSKAP EN DIE STUDIE VAN LITERATUUR

Rudolf P. Botha

Wat kan Taalwetenskap die student van literatuur bied?

Basiskonsepte vir die doseer van taal en literatuur in die konteks

van 'n vreemde kultuur

Wilhelm Liebenberg

Die rol van die Taalwetenskap in die ontwikkeling van die Literatuurwetenskap

Henning Snyman

Implikasie as taalverskynsel

Johan C. Thom en Pieter G.R. de Villiers

klassieke tekste

SPIL PLUS 9 (198A)

Hester Waher

Chomsky se teorie van 'government-binding'

SPIL PLUS 10 (1985)

AFDELING I

ALGEMENE PERSPEKTIEWE OP DIE NORMERING VAN TAALGEBRUIK

D.D. Joubert

'n Sosiologiese konsepsie van norme

Algemene aspekte van taalnormering

V.N. Webb

W.K. Winckler

$108-122$

Oor die taalwetenskaplike gronde van taalgebruiksnorme:

"important" of "importantly"?

R.P. Botha en M. Sinclair

Die negende gebod in talgebruik

AFDELING II

PERSPEKTIEWE OP DIE PRAKTYK VAN DIE NORMERING VAN AFRIKAANS

E. Raidt

Historiese perspektief op die normering van Afrikaans

L.C. Eksteen

Die rol van die Akademie in die standaardisering van die Afrikaanse spelling

D.C. Hauptfleisch

Taainormering en woordeboeke: 'n Praktykgerigte perspektief 
451

T.J.R. Botha

Normering in die Afrikaanse Radio- en Televisiediens

J. Picard

Die normering van Afrikaanse vakterminologie

J.S. Schutte

$292-320$

Die taalpraktisyn as kruispunt

$321-327$

Die Staatstaaldiens: Funksies en invloed ten opsigte van die normering van taalgebruik

G. Kroes

Die doeltreffendheid van die Afrikaanse Woordelys en Spelreêls

as handleiding en naslaanbron by die onderrig van Afrikaans op tersiêre vlak

J.P. Botha

Die normering van Afrikaanse taalgebruik soos beoefen in die skool en die universiteit

J.M. Marais

Taalnormering in die skool: 'n onderwyser se perspektief

J. Esterhuyse

Die dominasie van die Afrikaner-lewensbeskouing binne die

vir hoërskole

L.R. Heiberg

Taaldokters

A. Gardiner

Die Afrikaanse taaldokter en die Hippokratiese eed: implikasies

vir die taalgebruiker

H. Snyman

Norme by literêre taalgebruik

C.J. Conradie

Die normering van Afrikaanse Bybeltaal

AFDELING III

PERSPEKTIEWE OP DIE NORMERING VAN ANDER TALE

E. Loubser

Normering op die Nederlandse taalgebied

E. Ridge

Norms in British and South African English

S. Skorge

Norme en normkritiek ten opsigte van die Duitse taal:

'n kort oorsig

P. Brink

$554-572$

Taainormering in Frankryk 
SPIL PLUS 11 (1987)

Rudolf P. Botha

The generative garden game: challenging Chomsky at conceptual combat

SPIL PLUS 12 (1989)

Jan B. Bedaux

SPIL PLUS 13 (1989)

C. le Roux

On the interface of morphology and syntax

The Metaphysics Market. 1 Merchandizing language as matter

SPIL PLUS 15 (1989)

Rudolf P. Botha

The Metaphysics Market. 2 Billing language as behavioural

SPIL PLUS 16 (1991)

Hester Waher

Oor grense, kettings, en lisensies. 'n Sleutel tot Chomsky se teorie van grammatika

\section{SPIL PLUS 17 (1991)}

Rudolf P. Botha

The Metaphysics Market. 3 Selling language as soul

SPIL PLUS 18

M. Sinclair and W.K. Winckler

Relevance Theory. Explaining verbal communication

SPIL PLUS 19 (1991)

Rudolf P. Botha

The Metaphysics Market. 4 Pushing language as Platonic (not to mention Popperian)

\section{SPIL PLUS 20 (1991)}

Rudolf P. Botha

The Metaphysics Market. 5 Stocking language as something 


\section{SPIL PLUS 21 (1992)}

TAALWETENSKAP VIR DIE TAALPROFESSIES 1: DEEL A LINGUISTICS FOR THE LANGUAGE PROFESSIONS 1: PART A

R.P. Botha

Charting the anatomy of linguistic reality

Johann L. van der Walt

Linguistics and second language teaching: An assessment

Gary P. Barkhuizen

What we want from linguistics: A plea from high school

English teachers

Elizabeth de Kadt

Contrastive analysis, pragmatics and language teachers?

Vivian de Klerk

Why language teachers need linguistics

Elaine Ridge

Communicative language teaching: Time for review?

M.S. Odendaa

Error correction in a communicative language teaching framework

Peter Southey

Fossilization in English second language medium

H.W. Broekman

Circular interaction between linguistic departments and language departments

Marianna Visser

Theoretical syntax in second language acquisition research and in second language classroom research

M. Viljoen

Wat is dit wat ons met behulp van ' $n$ taaltoets evalueer?

Norah Haussmann

What exactly are we testing when we claim to be testing mothertongue communicative competence?

J. de Vynck

Taalgebruik en taalbeheersing: twee Franse modelle

J. Keith Chick

A role for linguistics in addressing contextual issues relevant to second language teaching

Christine Anthonissen

The relevance of speech act theory for research on the acquisition of pragmatic competence by second language leamers

Cecile le Roux

The problem of ethnocentric bias in speech act studies: Implications

for language teaching 
Rosemary Granger

The problem of non-standard utterances used by speakers of English

as a second language at tertiary level

Margaret Inglis understanding of scientific concepts

Ninon Roets

Insette uit die toegepaste linguistiek vir 'n kursus vir akademiese doeleindes

E. Hilton Hubbard

Linguistics as a subversive activity: Exploding myths and misconceptions in the language classroom

H. Menkveld

Die problematiek rondom die ondenig van Afrikaans (T1)

Hildegard van Zweel

Factors influencing the transition from orality to literacy

Myrtle Hooper

The rhetorics of audience consciousness: A dialogic approach to reading Donne in Zululand

Lydia McDermott

Literary analysis and exposition: The second language reader-writer

SPIL PLUS 22 (1992)

TAALWETENSKAP VIR DIE TAALPROFESSIES 1: DEEL B LINGUISTICS FOR THE LANGUAGE PROFESSIONS 1: PART B

LITERERE KRITIEK EN ANALISE / LITERARY CRITICISM AND ANALYSIS

Henning H.J. Snyman

Linguistiese ondersoek en gediganalise: noodwendige verstrengeling of marginale oorvleueling?

J.T. von Gruenewaldt

The relevance of linguistic theories in the analysis of literary texts

VERTALING EN TEKSWETENSKAP / TRANSLATION AND TEXT

Melinda Sinclair

The effects of context on utterance interpretation: Some questions and some answers 
Ferdinand Deist

Bible translation and relevance theory

Gerrie Snyman

The theologian's search for "Meaning": Restraint or liberation of the creative spirit?

C. van Schalkwyk

Vertaling - 'n diskursiewe doenigheid

G. Kroes

Die inhoud en plek van norme in die vertaalpraktyk, vertaalkunde, vertaalkritiek en die vertaalwetenskap

J. du T. McLachlan

Terug na Trap der, Jeugd: 'n praktykbeskouing van die resultaat van taalopleiding

Anna-Marie Beukes

Die vertaalberoep en taalbeplanning

Walter K. Winckler

Missing Matthew's meaning. Or: Towards a nodding acquaintance with 'Textual Meaning' (and, maybe, with 'Context' too)

Judith A. Campbell

Semantic representation and the translation of poetry

M.E. Nelson

Perspektiewe uit die tekswetenskap op die vertaling van eiename in 'n kinderboek

$192-224$

Alet Krugen

Die beredeneerde betoog in die afstandonderrig van vertalers

LEKSIKOGRAFIE / LEXICOGRAPHY

Piet Swanepoel

Leksikografie en linguistiek

F.J. Lombard

Leksikograaf, woordeboekgebruiker en taalwetenskaplike

' $n$ kongruente of inkongruente driehoek?

John R. Taylor

How many meanings does a word have?

A.E. van Niekerk

$358-370$

Maria Smit

Translating culture-bound words: A problem in bilingual

lexicography

Ernst F. Kotzé

Die probleem van grammatikale ekwivalensie by 'n vertalende aanleerderswoordeboek 
Xlaus Menck

Die woordeboek as hulpmiddel - en nie as struikelblok - in vreemdetaalonderrig

\section{SPRAAKTERAPIE / SPEECH THERAPY}

E. Alant

$407-416$

Die tersaaklikheid van taalwetenskap vir spraakheelkunde

Speech-language therapy with Zulu clients: Implications for

linguistics

INLIGTINGKUNDE / INFORMATION SCIENCE

L.G. de Stadler and M,W. Coetzer

$439-448$

A morphologícal parser for Afrikaans

$449-466$

C.S. Johl

Die relevansie van linguistiek en literatuurwetenskap in ' $n$ post-apartheidgemeenskap

David Brown

Sociolinguistic practice and political change: Critical appraisal

of the language atlas of South Africa

Walter McKay

Marginal limitations: Report from a vanishing empire

V. Prabhakaran

$485-499$

The political situation as a factor in shift and maintenance of the Telugu language in South Africa

SPIL PLUS 23 (1994)

Paul T. Roberge

The formation of Afrikaans

Rudolf P. Botha

The World of Language: 1 Its crust

Rudolf P. Botha

The World of Language: 2 Its behavioural belt

SPIL PLUS 26 (1994)

TAALWETENSKAP VIR DIE TAALPROFESSIES 2 LINGUISTICS FOR THE LANGUAGE PROFESSIONS 2

TAALTEORIE: IMPLIKASIES / LINGUISTIC THEORY: IMPLICATIONS

Roy Dace 
Cecile le Roux

Modular minds and input in second language acquisition

Parameterverstelling en tweedetaalverwerwing

TAALTEORIE: TOEPASSINGS / LINGUISTIC THEORY: APPLICATIONS

Yvonne Barnard

A language plan for primary school teacher education

Heila Jordaan

Language intervention to facilitate the acquisition of a second language by pre-school children

Philip Lewis

The acquisition of clicks by non-mother-tongue speakers

C. van der Walt

The acquisition of transactional competence in writing: a case study

TAALVERSKEIDENHEID: MANIFESTASIES EN IMPLIKASIES / LINGUISTIC DIVERSITY: ITS MANIFESTATIONS AND IMPLICATIONS

Elizabeth Mathakga Botha

Manifestation of language varieties in the classroom in the PWV

The practical implications for writers, publishers, and policy-makers

of the various policy options on the medium of instruction in future South African schools

R. Mesthrie

Standardisation and variation in South African English

Abner Nyamende

Regional variation in Xhosa

\section{STILISTIEK / LINGUISTIC STYLISTICS}

E. Hilton Hubbard

A functional-syntactic perspective on gender stereotyping in popular fiction

J.T. von Gruenewaldt

A stylistic approach to the teaching of poetry with specific reference

to Sepamla's poem The Blues is You in Me

\section{KRITIESE TAALWETENSKAP / CRITICAL LINGUISTICS}

Christine Anthonissen

Distinguishing between critical linguistics and critical language awareness: implications for first language teaching in secondary schools

R.P. Botha

Teaching language with the aid of Rottweilers, sharks and dinosaurs

Jenny Clarence

"Tensed" and "bumpered" in a university context: the case for the integration of critical linguistics into language programmes 
Jeanne Maartens

Teaching Afrikaars as emancipatory discourse

Hildegard van $Z$ wee

Some insights that orality-literacy studies can offer language teachers

SPIL PLUS 27 (1995)

Rudolf P. Botha

The World of Language: 3 Its capacities stratum

SPIL PLUS 28 (1995)

Rudolf $P$. Botha

The World of Language: 4 Its codelike core 